\title{
Pharmacological, nutritional and allelopathic attributes of noxious weed, Trianthema portulacastrum L. (Horse purslane).
}

\author{
Anum Ara, Abida Akram, Maryam Ajmal, Shaista Akhund* and Brian \\ Gagosh Nayyar \\ Department of Botany, PMAS Arid Agriculture University Rawalpindi, Pakistan \\ *Corresponding author's email: shaistaakhund@ hotmail.com
}

\section{Citation}

Anum Ara, Abida Akram, Maryam Ajmal, Shaista Akhund and Brian Gagosh Nayyar. Pharmacological, nutritional and allelopathic attributes of noxious weed, Trianthema portulacastrum L. (Horse purslane). Pure and Applied Biology. Vol. 4, Issue 3, 2015, pp 340-352. http://dx.doi.org/10.19045/bspab.2015.43010

\begin{tabular}{lll}
\hline \hline Received: 06/05/2015 & Revised: 22/08/2015 & Accepted: 28/08/2015 \\
\hline
\end{tabular}

\section{Abstract}

Trianthema portulacastrum L. generally known as horse purslane, is a noxious weed of Family Aizoaceae. The plant is native to South Africa and has been reported to be present in India, Pakistan, Tropical America, West Asia, Srilanka and Africa. It is a diffuse, prostrate, branched succulent annual herb which is considered to be a noxious weed due to high level of infestation in various crops. Trianthenol, ecdysterone and leptorumol are various phytochemicals which has been isolated from this plant. It is an important medicinal plant which is mostly used for fever, jaundice, dropsy, liver and kidney diseases and also well known for its hepatoprotective, anticarcinogenic, diuretic, antimicrobial, antinephrotoxic and antidiabetic activities. Plant is also used as vegetable in various parts of world due to its high nutritional value. This paper gives information on pharmacological attributes, nutritional benefits, allelopathic impact on other plants and effective management of Trianthema portulacastrum Linn so that it can be can be used in a positive way especially for the development of new drugs.

Key words: Medicinal Plant, Hepatoprotective, Allelopathic, Antioxidant.

Introduction

\section{Geographical Distribution}

Trianthema portulacastrum L. is an annual terrestrial weed of the Family Aizoaceae. The plant is native to South Africa and also reported to be present in India, Tropical America, West Asia, Srilanka and Africa [1]. It is one of the major summer crop weeds in Pakistan [2] and is widely distributed in Punjab and Sindh regions whereas in India, it has been reported to be present in Uttar Pradesh, Rajasthan, Haryana, Punjab and Delhi causing infestation in various economically important crops [1, 3].

\section{Botanical description}

The plant is commonly known as horse purslane. Synonyms of Trianthema portulacastrum Linn. are Trianthema monogyna Linn. and Trianthema obcordata Roxb. It is a diffuse, prostrate, branched succulent annual herb. The height of stem is 
$35 \mathrm{~cm}$ and it is glabrous to sparsely pubescent (Figure 1a). The leaves of Trianthema portulacastrum L. are suborbiculate to obovate, $1.5-2.6 \mathrm{~cm}$ in length, $0.6-2.5 \mathrm{~cm}$ broad, obtuse or acute. The length of petiole is $4-11 \mathrm{~mm}$ and its base is dilated. Flowers are axillary solitary and sessile (Figure $1 \mathrm{~b}$ ). Calyx tube is closely covered by the leaf base. Sepals are five in number, oblong, 2.5-3.0 mm in length, shortly aristate. Stamens are $10-15$ in number, unequal in size and length of filaments is $1.5-2.2 \mathrm{~mm}$. Ovary is $2 \mathrm{~mm}$ long, and almost conical in shape. It has one style which is linear, 1.5-2.0 mm long and persistent. Seeds are $2 \mathrm{~mm}$ broad and black in colour [4].

\section{Germination and Growth}

Trianthema portulacastrum is a noxious weed which leads to crop damage at high density. The plant grows rapidly and forms a carpet on the soil due to its prostrate growth [5]. It grows quickly if water is available and has vegetative growth for 35-40 days after emergence. It shows maximum germination at $35^{\circ} \mathrm{C}$ and increase in $\mathrm{pH}$ results in increased germination while at $\mathrm{pH}$ 5 it shows lowest rate of germination. High levels of salinity also affects germination [6].

\section{Biological activities}

Medicinal properties of Trianthema portulacastrum $\mathrm{L}$. has been reported by many researchers as it contains various biologically active constituents such as steroids, flavonoid, alkaloids, terpenes, carbohydrates, tannins and fats.

\section{Antiliathic activity}

Treatment of experimentally induced urolithiasis with ethanolic extract of leaves of Trianthema portulacastrum Linn. resulted in a restoration of urinary and serum parameters along with significant increase in activity of antioxidant enzymes [7].

\section{Antioxidant activity}

Methanolic extract plant showed antioxidant activity against 1, 1-Diphenyl-2 picryl hydrazyl (DPPH) and hydrogen peroxide radicals which was comparable with standard ascorbic acid [8]. Another study reported that stem leave and root hydrolysates of Trianthema portulacastrum L. possess reducing potentials, have capability to inhibit peroxidation (43.26 89.98\%), and radical scavenging ability (6.98 311.61 $\mu \mathrm{g} / \mathrm{mL}$ IC50) thus indicating $T$. portulacastrum as potent source of antioxidants [9].

\section{Antihyperglycemic Activity}

Diabetes is a complex disorder which leads to micro \& macro vascular complications involving lack of insulin secretion or insulin resistance or both. Diabetes has reached epidemic proportions [10]. Various research studies has been conducted for the evaluation of plants extracts for their antidiabetic activity [11]. Many plants have been known for their antihyperglycemic activity through folklore. Laboratory tests carried out in normal and alloxan induced diabetic rats showed that methanolic extract of Trianthema portulacastrum L. produced significant reduction in blood glucose [12]. According to another reported study methanolic extract of horse purslane produced antihyperglycemic activity comparable to satandard, Glibenclamide in streptozotocin induced diabetic rat [13].

\section{Antimicrobial activity}

Methanolic, chloroform and aqueous extracts of Trianthema portulacastrum $\mathrm{L}$. exhibited antibacterial activity against seven bacterial isolates; Klebsiella pneumonia, Proteus vulgaris, Shigella flexneri, Pseudomonas aeruginosa, Staphylococcus aureus, Salmonella typhi and Escherichia coli. While evaluation of anti-fungal activity against Aspergillus fumigatus, Rhizopus oryzae, Aspergillus flavus, 
Aspergillus niger, Mucor indicus and Candida albicans showed that methanol and chloroform extracts displayed less than $100 \%$ inhibition against Aspergillus niger, Aspergillus fumigatus, Rhizopus and Candida albicans whereas Mucor did not show any susceptibility to all the three leaf extracts [14]. According to another study the inhibitory activity of both trianthenol and crude extract of Trianthema portulacastrum L. was found to be average [15].

Antibacterial activity of selected Thai weeds against different bacterial isolates i.e, Plesiomonas shigelloides, Aeromonas caviae, Edwardsiella tarda, Aeromonas hydrophila, Salmonella spp., Ralstonia spp., Shigella spp. and Xanthomonas campestris pv. Vesicatoria showed that ethanol extract of horse purslane had $20.10 \%$ inhibition against Shigella spp. [16]. Root extract of horse purslane against Staphylococcus aureus, Bacillus subtilis, Escherichia coli, Proteus vulgaris and Pseudomonas aeruginosa showed significant anti-bacterial activity which is comparable to cotrimoxazole [17].

\section{Antinephrotoxicity}

Results of studies carried on gentamicin induced nephrotoxicity in rats showed that T. portulacastrum possess nephroprotective activity and free radical scavenging activity [18]. Methanolic extract of $T$. portulacastrum L. provide defense against atherosclerotic diet or CCT diet (containing $4 \%$ cholesterol, $0.5 \%$ thiouracil and $1 \%$ cholic acid) induced glomerulosclerosis and hepatic injury in rats. The extract reduced the levels of serum lipid such as alanine transaminases and aspartate transaminases and also reduced creatinine levels [19]. Trianthema portulacastrum leaves extract provide relief against adriamycin induced nephrotic syndrome by reducing the serum cholesterol, blood urea nitrogen, and creatinine $[20]$.

\section{Diuretic activity}

Crude extract of Trianthema at the dose of $50 \mathrm{mg} / \mathrm{kg}$ displayed $79 \%$ diuretic activity by increasing urinary volume and urinary electrolytes concentration comparable to standard, furosemide, thus suggesting it to be a potential [21].

\section{Anticarcinogenic activity}

Investigations have revealed that administration of the chloroform extract of $T$. portulacastrum provide relief against diethylnitrosoamine (DENA) induced hepatocarcinogenesis [22] and diethylnitroso- amine-induced phenobarbital promoted hepatocarcinogenesis [23].

\section{Hepatoprotective activity}

The outcomes of study against thioacetamide and paracetamol induced hepatotoxicity revealed significant hepatoprotective activity of $T$. portulacastrum which was evaluated by using different biochemical parameters [24] .Ethanolic extract of Trianthema portulacastrum showed hepatoprotective activity against liver injury in mice induced by carbon tetrachloride (CCl4), comparable to silymarin, a well-known hepatoprotective agent [25]. Oral feeding with the ethanolic extract (from 2 weeks before $\mathrm{CCl} 4$ treatment up to 13 weeks) provided protection against DNA damage [26]. Pre-treatment with $T$. portulacastrum for seven days reduced the serum enzymes levels thus showing hepatoprotective activity of Trianthema similar to silymarin [27]. Oral treatment with the extract $(100$ or $150 \mathrm{mg} / \mathrm{kg})$ provided protection against $\mathrm{CCl} 4$ damage and reduced elevated lipid peroxidation of the liver [28]. In another study Trianthema portulacastrum L. ethanolic extract reduced hepatocellular destruction of Swiss albino mice [29].

\section{Anthelmintic activity}

Crude aqueous methanolic extract of Horse purslane showed anthelmintic activity 
against mature female Haemonchus contortus and their eggs (In vitro) while In vivo anthelmintic activity was carried out in sheep infected with different nematodes species [30].

\section{Antihyperlipidemic}

Investigations revealed that methanolic extract of Trianthema portulacastrum L. provides protection to hyperlipidemic rats by reducing lipid levels [31] and by reducing triglycerides and total cholesterol [12].

\section{Antifertility Activity}

Studies were carried out to assess the antifertility activity of Chloroform, alcohol and aqueous extracts of stem, leaves and roots of Trianthema portulacastrum $\mathrm{L}$. Results showed that extracts exhibited significant abortifacient activity ranging from $20.31 \%$ to $94.02 \%$.The alcoholic extract of was found to show strongest antifertility activity [32].

\section{Chemosterilant activity}

Ecdysterone obtained from horse purslane showed chemosterilant activity. The abdomens of house fly larvae were isolated and dipped in the crude extracts of Trianthema portulacastrum which revealed molting hormone activity [33].

\section{Analgesic activity}

Ethanol extract of $T$. portulacastrum showed analgesic activity by supressing writhing response induced by acetic acid. A dose of $250 \mathrm{mg} / \mathrm{kg}$ extract supressed writhing response by $50.92 \%$ as compared to standard drug Aspirin which blocks writhing response by $67.68 \%(\mathrm{P}<0.001)$. Apart from that the plant extract also showed significant antinociceptive action [34].

\section{Nutritional profile}

Food is the fundamental need of human being, but high rate of population causes shortage of fertile land causing hunger and malnutrition problems [35]. Plants have been used by human being as food, since prehistoric times. Although a few major crops have been used as food, but in many parts of the world, wild plants also contribute in daily intake of food [36]. Several wild species have been reported well for human consumption due to their nutritional values. Trianthema portulacastrum L. is also used as food by the people in some areas of world.

Nutritional assessment of $T$. portulacastrum L. revealed that it is a good source of fiber, proteins, potassium, sodium, and iron. Fiber was found to be the highest $(430.0 \mathrm{mg} / \mathrm{g})$, followed by ash $(348.0 \mathrm{mg} / \mathrm{g})$, moisture $(80.0 \mathrm{mg} / \mathrm{g})$, total protein $(91.9 \mathrm{mg} / \mathrm{g})$, carbohydrate $(30.2 \mathrm{mg} / \mathrm{g})$ and total lipid (20.0 $\mathrm{mg} / \mathrm{g}$ ). Among the macro minerals, potassium was present in higher concentration $(51.6 \mathrm{mg} / \mathrm{g})$ than sodium $(44.0$ $\mathrm{mg} / \mathrm{g})$ [37]. Another study reported Trianthema as a good source of fodder for ruminants as it contains various nutrients [38]. Analysis of chemical composition of Trianthema portulacastrum L. showed that it contains Edible portion (49g), Moisture $(90.0 \mathrm{~g})$, Protein $(2.5 \mathrm{~g})$ Ether extract $(0.33 \mathrm{~g})$, Ash (2.29g), Ca (52mg), P (22mg), K (317mg), Na (16.0mg), Mg (153mg), Iron (4.16mg), Zinc (0.46mg), Copper (0.12mg), Manganese $(0.43 \mathrm{mg})$ and Chromium (0.200mg) [39]. Another study conducted on eight different vegetable species revealed that Trianthema had the highest concentrations of fats and micronutrients compared to the other seven species, while fibre contents of Trianthema portulacastrum had nominal percentage values [40].

\section{Ethnobotanical uses}

Trianthema portulacastrum $\mathrm{L}$. is an important medicinal plant which is used worldwide to cure different diseases. Decoction of root is used for constipation by the local herbalists of Tamil Nadu, India [41]. The roots of Trianthema portulacastrum are used against jaundice by 
indigenous People in District Attock, Pakistan [42]. Various parts of plant are used for treating fever, rheumatism, jaundice, wounds, dropsy and liver diseases [43]. Necklace is made from the short pieces of stem and is hung around the neck to cure jaundice [44]. It is used as potherb in coimbatore districts of Tamil nadu and locally known as Charanai [45]. Juice of young roots used for cooling effect [46]. The leaves of horse purslane have medicinal properties which are used to promote urination and useful in dropsy and kidney disease [47].

\section{Phytochemistry}

About 2, 50,000 higher plant species are reported to be present on earth, of which more than 80,000 are medicinal due to presence of active constituents. Isolation of active components from plants and using it alone or in combination with others has opened new era, for the treatment of human disease. Plant based drugs have less side effects as compared to synthetic drugs that's why studies have carried out for development of methods to isolate active compounds from plant sources [48]. For this purpose many research studies have been conducted to detect the active constituents present in Trianthema portulacastrum L. Qualitative analysis of this plant showed the presence of various compounds such as steroids, flavonoid, alkaloids, carbohydrates, tannins, terpenes and fats.

Trianthenol (15-hydroxymethyl-2, 6, 10, 18, 22, 26, 30- heptamethyl-14-methylene-17hentriacontene) [15], a new flavonoid (5, 2'dihydroxy-7-methoxy-6, 8-dimethylflavone) and leptorumol (5, 7-dihydroxy-6, 8dimethylchromone) has been isolated from T. portulacastrum [49]. It also contains potassium salts, punarnavine, ecdysterone, and trianthemine. Roots of Horse purslane contain saponin glycoside [50]. Vanillic acid, P-Hydroxybenzoic acid, ferrulic acid,
trans-Cinnamic acid, Caffeic acid, Protocatechuic acid, o-coumaric acid and Pyrogallic acid, are also reported from leaves and stem of $T$. portulacastrum [51]. Ecdysterone has been isolated from the $T$. portulacastrum whole plant which is the most widely occurring phytoecdysone [52]. Phytochemical investigations of Trianthema portulacastrum revealed the presence of various compounds, mainly the flavonoids [14] 3, 4-dimethoxy cinnamic acid and Betacyanin [13].

\section{Allelopathic aspects}

Allelopathy is a phenomenon of useful or harmful effects of a plant (on its own or other plants) which can have multiple effects on plant distribution and biodiversity conservation [53]. Allelochemicals can either stimulate or supress growth of another plant [54]. Trianthema portulacastrum is a serious weed of cotton and maize crops reducing crop yields by $32 \%$ [55]. It has become a noxious weed due to competition with many important crops like millet, maize, wheat, sorghum, mash, mungbean, guar and sunflower [56].

Evaluation of the allelopathic potential of Trianthema portulacastrum L. on germination and growth of sesame (Sesamum indicum L.) showed that the low concentrations had no significant effect whereas treatments with higher concentrations had negative effects [57]. Studies showed that the stem and whole plant extract of Trianthema portulacastrum reduced the dry matter production of soyabean [58]. Studies on allelopathic potential of Trianthema portulacastrum L. and Sesuvium portulacastrum L. showed that plant extract of Trianthema portulacastrum proved harmful to all tested crops than S. portulacastrum [59]. Pre sowing soaking of rice in $T$. portulacastrum leaf extract suppressed germination and growth of rice [60]. Studies on the influence 
of Trianthema portulacastrum and Zea mays plant spacing on maize grain yield and quality revealed that $T$. portulacastrum reduced starch and protein contents as compared to control at different weed densities [61]. According to a reported study Horse purslane infests soybean and affects growth, net assimilation rate, dry weight, height and leaf area index [62]. Analysis of interactive allelopathic effects of Zea mays and $T$. portulacastrum showed that both plants possess allelopathic potential [63]. Studies carried out to quantify the impact of Trianthema on maize, revealed that it is a strong competitor of maize and may cause significant losses in maize crop yield [64].

The effect of allelopathy on many aspects of plant ecology had a red check history among ecologists [65]. Allelopathy plays an important role in invasion of exotic plant species [66]. Studies were carried out for searching positive association between Trianthema portulacastrum and Amaranthus viridis in terms of allelopathic potential. Findings showed the density of Amaranthus viridis increased in the area infested by Trianthema portulacastrum. Apart from that seeds treated with Trianthema extracts showed high germination percentage as compared to untreated seeds thus supporting the ecological importance of allelopathy [51].

\section{Pests and Diseases}

Fusarium chlamydosporum Wollenw. \& Reinking was recognised as causal agent of horse purslane leaf spot disease and pathogenicity was confirmed through In vitro inoculation of pathogen [67]. In another study In vitro pathogenicity studies on Horse purslane were conducted using spore inoculum of Gibbago trianthemae which was reisolated from inoculated plants and confirmed its host specificity on Horse purslane [68].

\section{Management}

Horse purslane (Trianthema portulacastrum L.) is a noxious weed of different economically important crops which is mostly managed through mechanical method but this method is time consuming and very expensive [69]. Herbicides are most commonly used to control $T$. portulacastrum but herbicides have harmful effects on human health, agriculture and environment [70]. Thus allelopathy is a new approach for controlling weeds which is cost effective and eco-friendly [71]. Certain chemicals known as allelochemicals are released from different plants that suppress growth of plants. These allelochemicals can be used as an alternative to herbicides as they are ecofriendly and safe to use.

Experiments were conducted to investigate the effect of allelochemicals of various plants like Sorghum, Horse purslane, Sun flower, Parthenium, Eucalyptus and Datura on germination and growth of horse purslane. According to results aqueous extracts of all tested plants have ability to suppress germination, root and shoot length of horse purslane [72]. Gibbago trianthemae Simmons, a hyphomycetous fungus reported on horse purslane can be used as a natural biocontrol agent to control horse purslane [73]. Wheat residues and wheat-infested rhizosphere soil have negative effects on germination and growth of horse purslane [74]. Higher concentration of extract of Sorghum bicolor reduced the germination, root and shoot length of Horse purslane by 15 to $20 \%$ while lower concentration increased shoot length of plant [2].

Tests were carried out to check the possible effects of combined allelopathic potential of sorghum, sunflower, brassica and mulberry tank mixed with atrazine on horse purslane. The results revealed that Atrazine alone supressed weed density up to $65-81 \%$, however allelopathic extracts of plants along 
with different doses ( $1 / 2$ and 1/3rd dose) of atrazine showed $70-75 \%$ suppression of weeds density [75]. Another study carried on combination of extracts of Helianthus annuus, Oryza sativa Brassica napus, Sorghum bicolor, Zea mays and Morus alba in suppressing germination and growth of Trianthema portulacastrum L. showed that higher concentration (100\%) of extracts of sunflower and Sorghum supressed germination of $T$. portulacastrum [76].

Herbicides are also used to control horse purslane. Studies were conducted for evaluation of soil applied herbicides alone or in combination with post emergence herbicides. According to results
Pendimethalin, flumioxazin, imazethapyr, Smetolachlor, or dimethenamid controlled horse purslane up to $73 \%$ while Pendimethalin in combination with diclosulam or followed by imazethapyr applied premergence controlled horse purslane up to 93\%. Along with that Pendimethalin followed by post emergence applications of acifluorfen or lactofen controlled horse purslane up to $92 \%$ while pendimethalin followed by post emergence applications of imazapic, diclosulam, imazethapyr, or 2, 4-DB controlled 80 to 88 $\%$ [77]. Acifluorfen and lactofen used alone, or in combination with 2, 4-DB controlled $T$. portulacastrum up to 70 per cent [78].
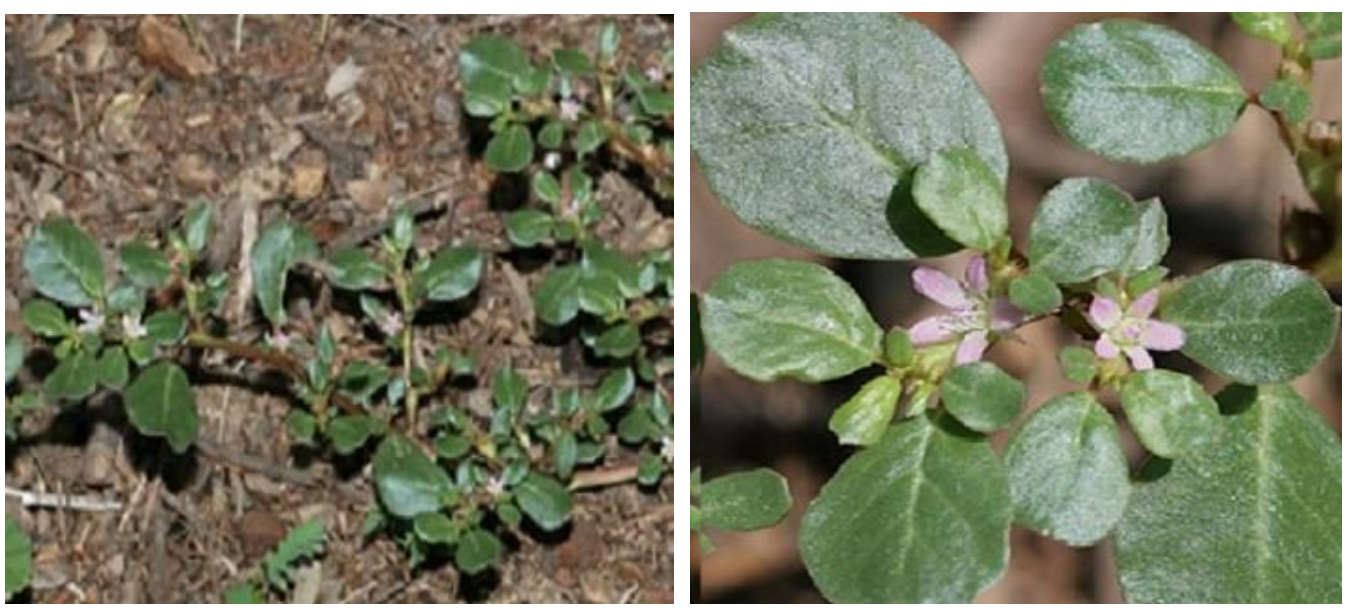

Figure 1. Trianthema portulacastrum L. Plant body (a) Flower and Leaf (b) Table 1. Hierarchical classification of Trianthema portulacastrum Linn.

$\begin{array}{ll}\text { Kingdom } & \text { Plantae } \\ \text { Subkingdom } & \text { Tracheobionta } \\ \text { Super division } & \text { Spermatophyta } \\ \text { Division } & \text { Magnoliophyta } \\ \text { Class } & \text { Magnoliopsida } \\ \text { Subclass } & \text { Caryophyllidae } \\ \text { Order } & \text { Caryophyllales } \\ \text { Family } & \text { Aizoaceae } \\ \text { Genus } & \text { Trianthema } \\ \text { Species } & \text { Trianthema portulacastrum L. }\end{array}$




\section{Conclusion}

From the above discussion it has been revealed that Trianthema portulacastrum is an important plant species with regard to its medicinal and nutritional properties. Although it is a major problematic weed but it can be effectively controlled and can be utilized in a positive way for the development of new drugs at low cost as it is easily available and tolerant to adverse conditions. Laboratory experiments have shown significant results, thus further studies are required to investigate all beneficial aspects of plant in order to develop new and efficient medicines which can be effectively used to cure various diseases.

\section{References}

1. Balyan RS \& Bhan VM (1986). Emergence, growth and reproduction of horse purslane (Trianthema portulacastrum) as influenced by environmental conditions. Weed Sci 34: 516-519.

2. Randhawa MA, Cheema ZA \& Ali MA (2002). Allelopathic effect of sorghum water extract on the germination and seedling growth of Trianthema portulacastrum. Int $J$ Agric Biol 4(3): 383-384.

3. Simmons EG (1986). Gibbago, a new phaeodictyoconidial genus of hyphomycetes. Mycotaxon 27: 107111.

4. Nasir E \& Ali SI (1977). Flora of West Pakistan. Deptt. of Bot. University of Karachi.

5. Senthil A, Chinnusamy C, Prabu KG \& Prabhakaran Nk (2009). Identification of threshold level of horse purslane (Trianthema portulacastrum) in irrigated cowpea (Vigna unguiculata). Indian J Crop Science 4(1): 141-143.
6. Tanveer A, Mumtaz K, Javaid MM, Chaudhry MN, Balal RM \& Khaliq A (2013). Effect of ecological factors on germination of horse purslane (Trianthema portulacastrum). Planta Daninha 31(3): 587-597.

7. Lakshmi S, Prabhakaran KV, Mallikarjuna G \& Gowthami A (2014). Antilithiatic Activity of Trianthema portulacastrum L. and Gymnema sylvestre R.Br against Ethylene Glycol induced Urolithiasis. Int J Pharm Sci Rev Res 25(1): 16-22.

8. Sunder AS, Reddy ARN, Prasad DK, Chander KP \& Vemula S (2010 a) Free Radical Scavenging Activity of Methanolic whole plant extract of Trianthema portulacastrum Linn. (Aizoaceae). Int J Ph Sci 2(2): 589592.

9. Yaqoob S, Sultana B \& Mushtaq M (2014). In vitro Antioxidant Activities of Trianthema portulacastrum L. Hydrolysates. Prev Nutr Food Sci 19(1): 27-33.

10. Bailey CJ \& Day C (1989). Traditional plant medicines as treatments for diabetes. Diabetes Care 12: 553- 564.

11. Daisy P \& Eliza J (2007). Hypoglycemic property of polyherbal formulation in streptozotocin induced diabetic rats. Biochem Cell Arch 7: 135-140.

12. Anreddy RNR, Porika M, Yellu NR \& Devarakonda RK (2010). Hypoglycemic and lipidemic activities of Trianthema portulacastrum Linn. Plant in normal and alloxan induced diabetic rats. Int J Pharmacol 6(2): 129-133.

13. Sunder AS, Rajyalakshmib G, Bharath A \& Rajeshwara Y (2009). Antihyperglycemic activity of Trianthema portulacastrum plant in 
streptozotocin induced diabetic rats. Pharmacologyonline 1: 1006-1011.

14. Kavitha D, Parvatham R \& Padma PR (2014). Assessment of Trianthema portulacastrum for its antimicrobial potential and investigation of their phytochemicals using HPTLC, GCMS, and IR. Int J Pharm Pharm Sci 6(1): 675-686.

15. Nawaz HR, Malik A \& Ali MS (2001). Trianthenol: an antifungal tetraterpenoid from Trianthema portulacastrum (Aizoaceae). Phytochemistry 56: 99-102.

16. Rattanata N, Daduang S, Phaetchanla S, Bunyatratchata W, Promraksa B, Tavichakorntrakoo R, Uthaiwat $\mathrm{P}$, Boonsiri P \& Daduang J (2014). Antioxidant and antibacterial properties of selected Thai weed extracts. Asian Pac J Trop Biomed 4(11): 890-895.

17. Kumar SS, Rajesh R \& Siddiqui AA (2006). Pharmacognostical and antibacterial activity of Trianthema portulacastrum L. Orient J Chem 2: 641-644.

18. Balamurugan G, Mohan CMJ \& Muthusamy P (2009). Protective effect of Trianthema portulacastrum Linn. leaves on gentamicin induced nephrotoxicity in rats. $J$ Nat Remedies 9(2): 165-169.

19. Sunder AS, Reddy ARN, Rajeshwar Y, Kiran G, Devkota KP \& Baburao B $(2010$ c). Protective effect of methanolic extract of Trianthema portulacastrum in atherosclerotic diet induced renal and hepatic changes in rats. Der Pharmacia Lettre 2: 540-5.

20. Karim S, Ashraf N, Kalam A, Jahan N, Jafri MA \& Ahmad G (2011). Effects of Biskhapra (Trianthema portulacastrum Linn.) leaves extract in adriamycin induced nephrotic syndrome. Int J Green Pharm 5(4), 329-335.

21. Asif M, Atif M, Malik ASA, Dan ZC, Ahmad I \& Ahmad A (2013). Diuretic activity of Trianthema portulacastrum crude extract in albino rats. Trop J Pharm Res 12 (6): 967-972.

22. Bhattacharya S \& Chatterjee M (1998). Protective role of Trianthema portulacastrum against diethylnitrosoamine-induced experimental hepatocarcinogenesis. Cancer Lett 129: 7-13.

23. Bhattacharya S \& Chatterjee M (1999). Inhibitory effect of Trianthema portulacastrum L. diethylnitrosoamine-induced phenobarbital promoted hepatocarcinogenesis. Neoplasma 46(2): 105-111.

24. Kumar G, Banu GS, Pappa PV, Sundararajan M \& Pandian MR (2004). Hepatoprotective activity of Trianthema portulacastrum L. against paracetamol and thioacetamide intoxication in albino rats. J Ethnopharmacol 92: 37-40.

25. Mandal A, Bishayee A \& Chatterjee M (1997 a). Trianthema portulacastrum affords antihepatotoxic activity against Carbon tetrachloride-induced chronic liver damage in mice: reflection in subcellular levels. Phytother Res 2: 216-221

26. Sarkar A, Pradhan S, Mukhopadhyay I, Bose SK, Roy S \& Chatterjee M (1999). Inhibition of early DNAdamage and chromosomal aberrations by Trianthema portulacastrum L. in carbon tetrachloride-induced mouse liver damage. Cell Biol Int 23: 703-800.

27. Banu GS, Kumar G \& Murugesan AG (2009). Ethanolic leaves extract of 
Trianthema portulacastrum L. Ameliorates Aflatoxin b1 induced hepatic damage in rats. Indian J Clin Biochem 24 (3): 250-256.

28. Mandal A, Bandyopadhyay S \& Chatterjee M (1997 b). Trianthema portulacastrum L. reverses hepatic lipid peroxidation, glutathione status and activities of related antioxidant enzymes in carbon tetrachlorideinduced chronic liver damage in mice. Phytomedicine 4(3): 239-44.

29. Mandal A, Karmakar R, Bandyopadhyay S \& Chatterjee M (1998). Antihepatotoxic potential of Trianthema portulacastrum against carbon tetrachloride-induced chronic hepatocellular injury in mice: Reflection in hematological, histological and biochemical characteristics. Arch Pharm Res 21(3): 223-30.

30. Hussain A, Khan MN, Iqbal Z, Sajid MS \& Khan MK (2011). Anthelmintic activity of Trianthema portulacastrum L. and Musa paradisiaca L. against gastrointestinal nematodes of sheep. Vet Parasitol 179: 92-99.

31. Sunder AS, Reddy ARN, Kiran G \& Thirumurugu $\mathrm{S} \quad(2010 \quad \mathrm{~b})$. Antihyperlipidemic and Antioxidant Activity of Methanolic Extract of Trianthema portulacastrum in Rats Fed a High-Fat Diet. J Herbs Spices Med Plants 16: 193-202.

32. Zade V, Pare S \& Dabhadkar D (2013). Evaluation of potential antifertility activity of plant Trianthema portulacastrum in female albino rat. Int J A PS BMS 2(1): 007-011.

33. Dinan L (2001). Phytoecdysteroids: Biological aspects. Phytochemistry 57(3): 325-39.
34. Shanmugam SK, Bama S, Kiruthiga N, Kumar RS, Sivakumar T \& Dhanabal P (2007). Investigation of analgesic activity of leaves part of the Trianthema portulacastrum (L) in standard experimental animal models. Int J Green Pharm 1: 39-41.

35. Pelletier DL, Frongillo EAJ, Schroeder DG \& Habicht JP (1995). The effects of malnutrition on child mortality in developing countries. Bull World Health Organ 73(4): 443-448.

36. Pieroni A, Houlihan L, Ansari N, Hussain B \& Aslam S (2007). Medicinal perceptions of vegetables traditionally consumed by southAsian migrants living in Bradford, Northern England. J. Ethnopharmacol 113: 100-110.

37. Khan N, Sultan A, Tahir N \& Jamila N (2013). Nutritional composition, vitamins, minerals and toxic heavy metals analysis of Trianthema portulacastrum L., a wild edible plant from Peshawar, Khyber Pakhtunkhwa, Pakistan. Afr $J$ Biotechnol 12(42): 6079-6085.

38. Bharathidhasan S, Babu NSG \& Balakrishnan V (2007). In vitro Evaluation of the nutritive value of Trianthema portulacastrum as a source of fodder for ruminants. Malays J Nutr 13(2): 179-187.

39. Gupta SA, Lakshmi J, Manjunath MN \& Prakash J (2005). Analysis of nutrient and antinutrient content of underutilized green leafy vegetables. LWT- Food Sci Technol 38(4): 339345.

40. Hussain J, Najeeb Ur Rehman, Khan AL, Hamayun M, Hussain SM \& Shinwari ZK (2010). Proximate and essential nutrients evaluation of selected vegetables species from 
Kohat region, Pakistan. Pak J Bot 42(4): 2847-2855.

41. Muthu C, Ayyanar M, Raja N \& Ignacimuthu S (2006). Medicinal plants used by traditional healers in Kancheepuram district of Tamil Nadu, India. J Ethnobiol Ethnomed 2: 43.

42. Naz I, Ahmad M \& Tamoor-ul-Hassan (2014). Ethnobotanical investigation of medicinal flora used by indigenous people in district Attock, Pakistan. J adv botany zool 1(4): 1-7.

43. Qureshi R, Waheed A, Arshad M \& Umbreen T (2009). Medicoethnobotanical inventory of tehsil Chakwal, Pakistan. Pak J Bot 41(2): 529-538.

44. Shah A, Marwat SK, Gohar F, Khan A, Bhatti KH, Amin M, Noor Ud Din, Ahmad M \& Zafar M (2013). Ethnobotanical study of medicinal plants of semi-tribal area of Makerwal \& Gulla khel (lying between Khyber pakhtunkhwa and Punjab provinces), Pakistan. Am J Plant Sci 4: 98- 116.

45. Ramachandran VS (2007). Wild edible plants of the Anamalais, Coimbatore district, Western Ghats, Tamil Nadu. Indian J Tradit Know 6(1): 173-176.

46. Kumar S, Parveen F, Goyal S \& Chauhan A (2008). Indigenous herbal coolents for combating heat stress in hot Indian arid zone. Indian J Tradit Know 7(4): 679-682.

47. Gulshan AB, Dasti AA, Hussain S, Atta MI \& Amin-ud-Din M (2012). Indigenous uses of medicinal plants in rural areas of Dera Ghazi khan, Punjab, Pakistan. ARPN J Agri Biol Sci 7(9): 750-762.

48. kumar RA, George VC, kumar RN \& Suresh PK (2012). A Review on the therapeutic potentials of parthenolide: A sesquiterepene lactone. Int Res J Pharm 3: 69-73.

49. Kokpol U, Wannachet-Isara N, TipPyang S, Chavasiri W, Veerachato G, Simpson J \& Weavers RT (1997). A C-methylflavone from Trianthema Portulacastrum. Phytochemistry 44(4): 719-722.

50. Ghani A (2003). Medicinal Plants of Bangladesh chemical constituents and uses. 2nd Ed. The Asiatic Society of Bangladesh, Dhaka (Bangladesh). 362-363, 502-505p.

51. Sherif EAA \& Gharieb HR (2011). Allelochemical effect of Trianthema portulacastrum L. on Amaranthus viridis L. supports the ecological importance of allelopathy. Afr $J$ Agric Res 6(32): 6690- 6697.

52. Banerji A, Chintalwar GJ, Joshi NK \& Chadha MS (1971). Isolation of ecdysterone from Indian plants. Phytochemistry 10: 2225-6.

53. Zhang KM, Lei S \& Yu LZ (2004). Fern allelopathy and its impact on biodiversity. Biodiversity Science 12: 466-471.

54. Putnam AR \& Weston LA (1986). Adverse impacts of allelopathy in agricultural system. In: Putnam AR., Tang SC, editors. The Science of Allelopathy: New York: John Wiley and Sons, Inc, pp. 235-239.

55. Balyan RS, \& Bhan VM (1989). Competing ability of maize, pearl millet, practices. Crop Res 2(2): 147153.

56. Nayyar MN, Ashiq M \& Ahmad I (2001). Major weed of Punjab. Manual on Punjab Weeds 1, 52-55.

57. Natarajan A \& Elavazhagan P (2014). Allelopathic influence of Trianthema portulacastrum L. on growth and developmental responses of sesame 
(Sesamum Indicum L.). Int J Curr

Biotechnol 2(3): 1-5.

58. Umarani R, \& Selvaraj JA (1996). Effect of Trianthema portulacastrum on Soybean. Allelopathy J 3: 261-266.

59. Asghar M, Tanveer A, Nadeem MA \& Ali HH (2013). Comparative allelopathic potential of two Aizoaceae weeds against germination of different crops. Pak. J. Weed Sci. Res 19(4): 377-391.

60. Mubeen K, Nadeem MA, Tanveer A \& Zahir ZA (2011). Allelopathic Effect of Aqueous Extracts of Weeds on the Germination and Seedling Growth of Rice (Oryza sativa L.). Pak J life Soc Sci 9(1): 7-12.

61. Randhawa MA, Khan MAJ, Khan NH \& Asif M (2009). Influence of Trianthema portulacastrum infestation and plant spacing on the yield and quality of maize grain. Int J Agric Biol 11(2): 225-227.

62. Hazra D, Tapas KD \& Yaduraju TN (2011). Interference and economic threshold of horse purslane (Trianthema portulacastrum) in soybean cultivation in northern India. Weed Biol Manag 11: 72-82.

63. Randhawa MA, Cheema ZA \& Saeed M (1999). Mutual allelopathic effects of maize and Trianthema portulacasturm on germination and seedling growth. Pak J Agri Sci 36: 14-16.

64. Saeed M, Marwat KB, Hassan G, Khan A \& Khan IA (2010). Interference of horse purslane (Trianthema portulacastrum L.) with maize (Zea mays L.) at different densities. Pak $J$ Bot 42(1): 173-179.

65. Fitter A (2003). Ecology Making Allelopathy Respectable. Science 301: 5 .
66. Bais HP, Vepachedu R, Gilroy S, Callaway RM \& Vivanc JM (2003). Allelopathy and Exotic Plant Invasion: From Molecules and Genes to Species Interactions. Science 301: 1377.

67. Aneja KR, Kumar V \& Sharma C (2014). Leaf-spot disease of Trianthema portulacastrum - a new record from world. J Innov Biol 1(2): 112-116.

68. Kumar PKR \& Gaddeyya G (2014). Host specificity of Gibbago trianthemae Simmons, a Phaeodictyoconidial Hyphomycetes fungus on Trianthema portulacastrum L. (Horse purslane). Int J Curr Microbiol App Sci 3(7): 461-470.

69. Brar AS Thind RJS, \& Brar LS (1995). Integrated weed control in upland cotton (Gossypium hirsutum L.). Indian J Weed Sci 27: 138-143.

70. Xuan TD, Tsuzuki E, Tawaha S \& Khanh TD (2004). Methods to determine allelopathic potential of crop plants for weed control. Allelopathy J 13: 149-164.

71. Yongqing MA (2005). Allelopathic studies of common wheat (Triticum aestivum L). Weed Biol Manag 5: 93-104.

72. Saeed M, Ashfaq M \& Gul B (2011). Effect of different allelochemicals on germination and growth of horse purslane. Pak J Bot 43(4): 21132114.

73. Aneja KR, Khan SA \& Kaushal S (2000). Management of Horse purslane (Trianthema portulacastrum L.) with Gibbago trianthemae Simmons in India. Proceedings of the $\mathrm{X}$ International Symposium on Biological Control of Weeds, 27-33. 
74. Khaliq A, Matloob A, Aslam F \& Khan MB (2011). Influence of wheat straw and rhizosphere on seed germination, early seedling growth and biochemical attributes of Trianthema portulacastrum. Planta Daninha 29(3): 523-533.

75. Khan MB, Ahmad M, Hussain M, Jabran K, Farooq S \& Waqas-UlHaq M (2012). Allelopathic plant water extracts tank mixed with reduced doses of atrazine efficiently control Trianthema portulacastrum L. in Zea mays L. J Anim Plant Sci 22(2): 339-346.

76. Mahmood A, Cheema ZA, Khaliq A \& Hassan AU (2010). Evaluating the potential of allelopathic plant water extracts in suppressing horse purslane growth. Int J Agric Biol 12: 581-585.

77. Grichar WJ (2008). Herbicide Systems for Control of Horse Purslane (Trianthema portulacastrum L.), Smell melon (Cucumis melo L.), and Palmer Amaranth (Amaranthus palmeri S. Wats) in Peanut. Peanut Sci 35: 38-42.

78. Grichar WJ (1993). Horse purslane (Trianthema portulacastrum) control in peanut (Arachis hypogaea). Weed Technol 7: 570-572. 